\title{
Isolation and Insecticidal Potential of Native Bacillus thuringiensis against Helicoverpa armigera and Spodoptera litura
}

\author{
Ankit S. Patel ${ }^{1 *}$, Harsha N. Shelat ${ }^{1}$ and Hiren K. Patel ${ }^{2}$ \\ ${ }^{1}$ Department of Agricultural Microbiology, BA College of Agriculture, Anand Agricultural \\ University, Anand (GJ), India \\ ${ }^{2}$ AICRPWeed Management, Anand Agricultural University, Anand (GJ), India \\ *Corresponding author
}

A B S T R A C T

\begin{tabular}{|c|}
\hline Keywords \\
\hline $\begin{array}{l}\text { Areca nut, UHPLC, } \\
\text { Redox titration, } \\
\text { Vitamin } \mathrm{B}_{6}, \\
\text { Vitamin } \mathrm{C}\end{array}$ \\
\hline Article Info \\
\hline $\begin{array}{l}\text { Accepted: } \\
15 \text { January } 2018 \\
\text { Available Online: } \\
10 \text { February } 2018\end{array}$ \\
\hline
\end{tabular}

\section{Introduction}

Biological control is a crucial tool of Integrated Pest Management. It involves the use of bio-agents like parasitoids, predators and insect pathogens e.g. fungi, bacteria, virus, nematodes etc. to manage the pests. Among these, bacterial bio-agents have gained significant attention since inception of insect pathology (Morales-Ramos et al., 2014). There are several families of entomopathogenic bacteria such as Bacillaceae, Pseudomonadaceae, Enterobacteriaceae, Streptococcaceae and
Micrococaceae which are used widely for insect pest management throughout world (Tanada and Kaya, 1993). Bacteria belonging to family Bacillaceae possess wide range of insecticidal activity; from which, $B$. thuringiensis $(B t)$ is the most widely used and successful microbial pesticide (Jurat-Fuentes and Jackson, 2012). B. thuringiensis was first discovered by Japanese biologist Ishiwata Shigetane in 1901. The sales of $B$. thuringiensis since its registration, account for more than $90 \%$ share amongst all microbial pesticides sold worldwide through its products represent about $1 \%$ of the total 
'agrochemical' market of fungicides, herbicides and insecticides across the world.

B. thuringiensis comprises of gram-positive, big rod shaped, spore-forming bacterium. They possesses unusual property of producing a parasporal protein crystal, popularly known as 'Cry' protein ( $\delta$-endotoxin), which is toxic to many insect pests (Crickmore et al., 2014). Efforts have been made in many countries to isolate new strains with increased potency against target pest insects having a wider host range. These toxins have not only shown activity against Lepidoptera, Diptera, Hymenoptera, Isoptera, Orthoptera and Coleoptera but also against nematodes, mites, lice, aphids and ants also (van Frankenhuyzen, 2009).

Thus, long established approach of isolating naturally existing strains of $B$. thuringiensis with novel toxicities is an attractive alternative. $B$. thuringiensis have been differentiated by various methods including presence of parasporal bodies, biochemical tests, serotyping, 16S rRNA gene sequencing, cell membrane fatty acid analysis, esterase production, antibiotic production, enzymes, phages and lectin grouping (El-kersh et al., 2012). Several biotechnological tools are available for rapid identification and differentiation of organisms (Sanahuja et al., 2011).

In various regions of the world, studies of $B$. thuringiensis have required new strains with different potentialities from those that are at present known for new cry genes with different insecticidal effects (Liang et al., 2011). Gujarat, India harbors diverse environments that are suitable for microorganism development, comprising natural sources for the isolation of new bacteria. In view of the biodiversity of the Middle Gujarat environment, isolation of $B$. thuringiensis isolates from this region may be helpful in finding new insect pathogen with combinations of cry genes, which are different from those currently known. Accordingly, this study aimed to isolate $B$. thuringiensis from soils of Anand district of middle Gujarat, for use in the microbial control of Helicoverpa armigera and Spodoptera litura.

\section{Materials and Methods}

\section{Isolation of $B$. thuringiensis from soil samples}

Native $B$. thuringiensis were isolated following the method described by Patel et al. (2013). One gram soil was added to $10 \mathrm{ml}$ of buffered T3 medium in a 100-ml flask and incubated at $100 \mathrm{rpm}$ at $30{ }^{\circ} \mathrm{C}$ for 36 to $48 \mathrm{~h}$. From this, $1 \mathrm{ml}$ broth was re-inoculated in 10 $\mathrm{ml}$ of buffered Luria Broth and incubated at $30{ }^{0} \mathrm{C}$ for 4-6 h on environmental shaker. One $\mathrm{ml}$ of broth was heat treated at $80{ }^{0} \mathrm{C}$ for 3 min in a water bath and allowed to settle at room temperature $\left(28 \pm 1{ }^{0} \mathrm{C}\right)$. The supernatant was transferred to sterile test tube, vortexed and serially diluted with sterile distilled water $\left(10^{-1}, 10^{-2}\right.$, and $\left.10^{-3}\right)$. From each dilutions, 500 $\mu \mathrm{l}$ aliquot was spread on Mannitol-Egg YolkPolymyxin (MYP) agar plates and incubated for $36-48 \mathrm{~h}$ at $30{ }^{0} \mathrm{C}$. Colonies with fried egg appearance (Off white, with irregular margin which produce red color and precipitation on MYP agar) were transferred on T3 agar plates and incubated at $30{ }^{0} \mathrm{C}$ for $72 \mathrm{~h}$. Isolated colonies obtained on T3 agar plates were examined microscopically for presence of spores and crystals under phase-contrast microscope as well as stained with $0.13 \%$ Coomassie brilliant blue stain. The cultures were then transferred on Nutrient agar slants and stored at $4{ }^{0} \mathrm{C}$ for further studies.

Establishment of Koch's postulates and preliminary toxicity test of native $B$. thuringiensis isolates

It is necessary to prove Koch's postulates for an organism to consider it as pathogen. So, 
accordingly, insect pathogens need to be screened for its pathogenicity against preferred host and it will give preliminary idea regarding its potency also (Poinar and Thomas, 1984).

Diet contamination technique (Navon et al., 1990) was employed to establish Koch's postulates. Test insects belonging to order Lepidopteran viz. H. armigera and S. litura were selected to establish Koch's postulates and preliminary toxicity test. Artificial diet for each test insect was prepared separately and mixed thoroughly with respective bacterial isolates approximately $10^{9} \mathrm{CFU} / \mathrm{ml}$ and fed to the respective test insects. Periodic mortality was recorded up to $120 \mathrm{~h}$. Haemolymph of the dead larvae was observed for the presence of spores and parasporal body of $B$. thuringiensis by preparing wet mounts, under 400X in Phase-Contrast Microscope.

Identification and characterization of native $B$. thuringiensis isolates

All isolates were identified based on their morphological, cultural and biochemical characteristics using $9^{\text {th }}$ edition of Bergey's Manual of Determinative Bacteriology and standard literature (Halt et al., 1994).

Based on the results of preliminary toxicity test, partial 16S rRNA gene sequencing was carried out for promising isolate and was performed using the ABI PRISM ${ }^{\circledR}$ BigDye $^{\mathrm{TM}}$ Terminator cycle sequencing kit on the ABI PRISM 3100 genetic analyzer (Chromous biotech). This sequencing has emerged as a powerful technique for phylogenetic placement, identification and diversity analysis of bacteria and was carried out using the set of primers suggested by Perez et al., 2007. The 16S rRNA gene sequences were assembled using MEGA 4 software, compared with other strains using NCBI
BLAST analysis for identification purpose and comparison of homologies of isolated strains with previously characterized strains.

Bioassays of Native $B$. thuringiensis isolate ABt 10 on Lepidopteran Pest

Laboratory bioassay of selected isolate $\mathrm{ABt}$ 10 was carried out by diet contamination technique (Navon et al., 1990) against $H$. armigera and $S$. litura along with standard strain of B. thuringiensis var. kurstaki HD-73.

A series of concentrations of isolate $\mathrm{ABt} 10$ and Btk HD-73 viz., 10 ${ }^{7}, 10^{8}$ and $10^{9} \mathrm{CFU} / \mathrm{ml}$ were prepared in sterile distilled water. The number of $B$. thuringiensis spores and crystals in the suspension was pre-determined microscopically using an improved Neubauer's haemocytometer. Each treatment was replicated four times having 10 larvae per each treatment. The observations on larval mortality were recorded at $24 \mathrm{~h}$ interval up to $168 \mathrm{~h}$. Dead larvae were recovered from the trays and presence of B. thuringiensis in the haemolymph was confirmed by observing the bacterial spores and crystals under 400X in a phase contrast microscope. Data were analyzed using Completely Randomized Block Design (Gomez and Gomez, 1984). Periodic observations were analyzed following the Analysis of Variance (ANOVA) method (Steel and Torries, 1980). Data were transformed using Arc sin transformation and subjected to statistical analysis. Insecticidal activities (LD50) of B. thuringiensis isolate Abt 10against the test insect was assessed following Probit analysis by Finney's method (Finney, 1971).

\section{Results and Discussion}

\section{Isolation of native $B$. thuringiensis from soil}

In present investigation, we approached to study the natural distribution of 
B. thuringiensis in the soils from diverse locations of Anand district. The type of soil from which the samples were collected was Sandy loam. Preliminarily 67 B. thuringiensis like colonies were selected for further screening from 109 isolated colonies on MYP agar plates. Fried egg like $B t$ and non- $B t$ distinguished from each other as $B t$ colonies gave pink coloration and precipitation of the medium around it, with an average of 3.94\% per samples. Selected 67 B. thuringiensis like isolates obtained after primary screening were further screened for presence of parasporal crystal inclusion body, popularly known as 'Cry protein' which is responsible for Bt's insecticidal activity using Trinocular PhaseContrast research microscope (400X) (Patel et $a l ., 2013)$. Total 9 isolates were screened out having presence of parasporal crystal body and designated as $B$. thuringiensis isolates ABt 2, 10, 17, 21, 33, 49, 54, 61 and 63, respectively. Isolate ABt10 obtained from Navli village shown larger size of inclusion body as compared to other isolates.

\section{Establishment of Koch's postulates for native B. thuringiensis}

Selected nine isolates shown presence of parasporal crystal inclusion body, which were subjected to establishment of Koch's postulates. According to Torres-Quintero et al. (2015) Koch's postulates is the basic step for establishing the microorganism as the causal agent of a disease to particular insect host. All nine isolates successfully proved Koch's postulates in the laboratory against $H$. armigera and $S$. litura as target insect with varying level of larvicidal activity after $120 \mathrm{~h}$. Typical symptoms recorded were cessation of feeding, paralysis, diarrhea, and vomiting. After passing through the gut epithelial barrier, pathogens proliferate in the hemocoel, producing bacteremia or septicemia as a result of the action of bacterial toxins and pathogenic factors; this typically results in color and tissue changes in the host. Insects killed by tested $B$. thuringiensis turned dark in color, soft and flaccid. Among the tested isolates, $\mathrm{ABt} 10$ gave maximum mortality $80 \%$ and above (Table 1) against both tested insects. Isolate ABt 10 possessed the largest inclusion body, which can be directly correlated with results of primary toxicity test where highest mortality was recorded (Whiteley and Schnepf, 1986).

\section{Characterization and identification of} native $B$. thuringiensis isolates

All the nine isolates were found gram positive, straight, thick, sporulating rods, occurring in long chains. The spores were ellipsoidal and sub terminal with round edges. Parasporal crystalline bodies were bipyramidal and smaller than spores (Fig. $1 \mathrm{~A}$ and B). On Nutrient agar the colony was round, medium sized, elevated with irregular margins and the color was creamish white, which later on showed dark center (Fig. 2 A and B). Similar results were found by Martin and Travers (1989) and Ashokan and Puttaswamy (2007) during their studies.

All the test isolates were confirmed $B$. thuringiensis by biochemical characters. In the present study, all the isolates were found positive for citrate utilization, production of catalase and arginine dehydrogenase enzyme. While malonate, Voges Proskauer's and ONPG tests were negative in this study.

Similar findings have also been reported by Lacey and Goettel (1995), Patel (2006) and Kaur et al. (2006). All the test isolates successfully fermented sucrose, glucose and trehalose, while for mannitol and arabinose fermentation the test isolates were found negative. The findings are comparable with the findings of Lacey and Goettel (1995), Patel (2006). 
After preliminary characterization and toxicity testing, isolate $\mathrm{ABt} 10$ acquired from Navli village soil (Anand) was identified at molecular level using 16S rRNA gene sequencing along with phylogenetic analysis and proceeded for further systemic insect bioassay against Lepidopteran insect pest $H$. armigera and S. litura.

Table.1 Efficacy of isolates against $H$. armigera and S. litura

\begin{tabular}{|l|c|c|c|}
\hline \multirow{2}{*}{ Sr. No. } & Isolate No. & \multicolumn{2}{|c|}{ Mortality } \\
\cline { 3 - 5 } & & H. armigera & S. litura \\
\hline $\mathbf{1}$ & ABt 2 & ++ & ++ \\
\hline $\mathbf{2}$ & ABt 10 & ++++ & ++++ \\
\hline $\mathbf{3}$ & ABt 17 & ++ & ++ \\
\hline $\mathbf{4}$ & ABt 21 & + & + \\
\hline $\mathbf{5}$ & ABt 33 & +++ & +++ \\
\hline $\mathbf{6}$ & ABt 49 & + & + \\
\hline $\mathbf{7}$ & ABt 54 & ++ & ++ \\
\hline $\mathbf{8}$ & ABt 61 & ++ & ++ \\
\hline $\mathbf{9}$ & ABt 63 & + & + \\
\hline Note: & $+=$ & Poor effect, & ++ \\
\hline
\end{tabular}

Table.2 Bioassay of Native $B$. thuringiensis isolate ABt-10 against $H$. armigera

\begin{tabular}{|c|c|c|c|c|c|c|c|}
\hline \multirow{2}{*}{$\begin{array}{l}\text { Treatments (spore- } \\
\text { crystal mixture } / \mathrm{cm}^{3} \text { ) }\end{array}$} & \multicolumn{7}{|c|}{$\%$ mortality after $h$} \\
\hline & 24 & 48 & 72 & 96 & 120 & 144 & 168 \\
\hline $\mathrm{T} 1-\mathrm{ABt} 10\left(\mathbf{1} \times \mathbf{1 0}^{\mathbf{7}}\right)$ & $\begin{array}{c}5.29 * \\
(0.85)^{* *}\end{array}$ & $\begin{array}{l}11.70 \\
(4.11)\end{array}$ & $\begin{array}{c}30.28 \\
(25.42)\end{array}$ & $\begin{array}{c}44.36 \\
(48.87)\end{array}$ & $\begin{array}{c}44.36 \\
(48.87)\end{array}$ & $\begin{array}{c}44.36 \\
(48.87)\end{array}$ & $\begin{array}{c}44.36 \\
(48.87) \\
\end{array}$ \\
\hline T2- ABt $10\left(\mathbf{1} \times \mathbf{1 0}^{\mathbf{8}}\right)$ & $\begin{array}{c}9.67 \\
(2.82)\end{array}$ & $\begin{array}{c}20.73 \\
(12.53)\end{array}$ & $\begin{array}{c}31.78 \\
(27.74)\end{array}$ & $\begin{array}{c}44.20 \\
(48.61)\end{array}$ & $\begin{array}{c}44.20 \\
(48.61)\end{array}$ & $\begin{array}{c}44.20 \\
(48.61)\end{array}$ & $\begin{array}{c}44.20 \\
(48.61)\end{array}$ \\
\hline T3- ABt 10(1 x 109) & $\begin{array}{c}20.47 \\
(12.23)\end{array}$ & $\begin{array}{c}33.05 \\
(29.75)\end{array}$ & $\begin{array}{c}50.83 \\
(60.11)\end{array}$ & $\begin{array}{c}69.53 \\
(87.77)\end{array}$ & $\begin{array}{c}69.53 \\
(87.77)\end{array}$ & $\begin{array}{c}69.53 \\
(87.77)\end{array}$ & $\begin{array}{c}69.53 \\
(87.77)\end{array}$ \\
\hline T4 -Btk HD-73(1 x 109) & $\begin{array}{l}14.05 \\
(5.90)\end{array}$ & $\begin{array}{c}28.23 \\
(22.37)\end{array}$ & $\begin{array}{c}45.00 \\
(50.00)\end{array}$ & $\begin{array}{c}63.81 \\
(80.52)\end{array}$ & $\begin{array}{c}63.81 \\
(80.52)\end{array}$ & $\begin{array}{c}63.81 \\
(80.52)\end{array}$ & $\begin{array}{c}63.81 \\
(80.52)\end{array}$ \\
\hline T5Control (Untreated) & $\begin{array}{c}0.91 \\
(0.03)\end{array}$ & $\begin{array}{c}0.91 \\
(0.03)\end{array}$ & $\begin{array}{c}0.91 \\
(0.03)\end{array}$ & $\begin{array}{c}0.91 \\
(0.03)\end{array}$ & $\begin{array}{c}0.91 \\
(0.03)\end{array}$ & $\begin{array}{c}0.91 \\
(0.03)\end{array}$ & $\begin{array}{c}0.91 \\
(0.03)\end{array}$ \\
\hline S. Em. & 3.69 & 3.31 & 2.12 & 2.14 & 2.14 & 2.14 & 2.14 \\
\hline $\mathrm{CD}$ at $5 \%$ & 11.13 & 9.99 & 6.39 & 6.45 & 6.45 & 6.45 & 6.45 \\
\hline C.V. $\%$ & 73.27 & 35.03 & 13.35 & 9.61 & 9.61 & 9.61 & 9.61 \\
\hline
\end{tabular}

* Figures in table are Arcsine transformed values.

** Figures in parentheses are the retransformed values 
Table.3 Bioassay of Native B. thuringiensis isolate ABt-10 against $S$. litura

\begin{tabular}{|c|c|c|c|c|c|c|c|}
\hline \multirow{2}{*}{$\begin{array}{c}\text { Treatments (spore-crystal } \\
\text { mixture } / \mathrm{cm}^{3} \text { ) }\end{array}$} & \multicolumn{7}{|c|}{$\%$ mortality after $\mathrm{h}$} \\
\hline & 24 & 48 & 72 & 96 & 120 & 144 & 168 \\
\hline $\mathrm{T} 1-\mathrm{ABt} 10\left(\mathbf{1} \times \mathbf{1 0}^{\mathbf{7}}\right)$ & $\begin{array}{c}5.29 * \\
(0.85)^{* *}\end{array}$ & $\begin{array}{l}18.12 \\
(9.67)\end{array}$ & $\begin{array}{c}33.29 \\
(30.12)\end{array}$ & $\begin{array}{c}48.88 \\
(56.74)\end{array}$ & $\begin{array}{c}50.32 \\
(59.23)\end{array}$ & $\begin{array}{c}50.32 \\
(59.23)\end{array}$ & $\begin{array}{c}50.32 \\
(59.23)\end{array}$ \\
\hline $\mathrm{T} 2-\mathrm{ABt} 10\left(\mathbf{1} \times \mathbf{1 0}^{\mathbf{8}}\right)$ & $\begin{array}{c}9.67 \\
(2.82)\end{array}$ & $\begin{array}{c}26.58 \\
(20.03)\end{array}$ & $\begin{array}{c}42.76 \\
(46.10)\end{array}$ & $\begin{array}{c}56.43 \\
(69.43)\end{array}$ & $\begin{array}{c}56.43 \\
(69.43)\end{array}$ & $\begin{array}{c}56.43 \\
(69.43)\end{array}$ & $\begin{array}{c}56.43 \\
(69.43)\end{array}$ \\
\hline T3- ABt 10(1 x 109) & $\begin{array}{c}20.47 \\
(12.23)\end{array}$ & $\begin{array}{c}39.17 \\
(39.89)\end{array}$ & $\begin{array}{c}56.95 \\
(70.25)\end{array}$ & $\begin{array}{c}69.53 \\
(87.77)\end{array}$ & $\begin{array}{c}69.53 \\
(87.77)\end{array}$ & $\begin{array}{c}69.53 \\
(87.77)\end{array}$ & $\begin{array}{c}69.53 \\
(87.77)\end{array}$ \\
\hline T4 -Btk HD-73(1 x 109) & $\begin{array}{l}14.05 \\
(5.90)\end{array}$ & $36.22(34.92)$ & $\begin{array}{c}49.39 \\
(57.63)\end{array}$ & $\begin{array}{c}63.81 \\
(80.52)\end{array}$ & $\begin{array}{c}63.81 \\
(80.52)\end{array}$ & $\begin{array}{c}63.81 \\
(80.52)\end{array}$ & $\begin{array}{c}63.81 \\
(80.52)\end{array}$ \\
\hline T5Control(Untreated) & $\begin{array}{c}0.91 \\
(0.03)\end{array}$ & $\begin{array}{c}0.91 \\
(0.03)\end{array}$ & $\begin{array}{c}0.91 \\
(0.03)\end{array}$ & $\begin{array}{c}0.91 \\
(0.03)\end{array}$ & $\begin{array}{c}0.91 \\
(0.03)\end{array}$ & $\begin{array}{c}0.91 \\
(0.03)\end{array}$ & $\begin{array}{c}0.91 \\
(0.03)\end{array}$ \\
\hline S. Em. & 3.69 & 3.31 & 2.61 & 2.28 & 2.20 & 2.20 & 2.20 \\
\hline $\mathrm{CD}$ at $5 \%$ & 11.13 & 9.98 & 6.86 & 6.87 & 6.64 & 6.64 & 6.64 \\
\hline C.V. $\%$ & 73.27 & 27.36 & 14.23 & 9.51 & 9.15 & 9.15 & 915 \\
\hline
\end{tabular}

* Figures in table are Arcsine transformed values.

** Figures in parentheses are the retransformed values.

Table.4 LD LD $_{50}$ of Native B. thuringiensis isolate ABt 10 and Btk HD-73 at various time intervals against $H$. armigera and $S$. litura

\begin{tabular}{|l|c|c|c|c|c|}
\hline Treatment & Time (h) & Chi $^{\mathbf{2}}$ & Slope & LD $_{\mathbf{5 0}}$ Value & Regression Equation \\
\hline \multirow{3}{*}{ H. armigera } & 48 & 0.165 & 0.335 & $8.497 \times 10^{10}$ & $\mathrm{y}=-3.662+0.335 \mathrm{x}$ \\
\cline { 2 - 6 } & 72 & 0.548 & 0.393 & $6.364 X 10^{8}$ & $\mathrm{y}=-3.463+0.393 \mathrm{x}$ \\
\cline { 2 - 6 } & 96 & 1.286 & 0.518 & $2.150 \times 10^{7}$ & $\mathrm{y}=-3.801+0.518 \mathrm{x}$ \\
\hline \multirow{3}{*}{ S. litura } & 48 & 0.076 & 0.370 & $7.812 \times 10^{9}$ & $\mathrm{y}=-3.661+0.370 \mathrm{x}$ \\
\cline { 2 - 6 } & 72 & 0.338 & 0.404 & $1.363 \times 10^{8}$ & $\mathrm{y}=-3.286+0.404 \mathrm{x}$ \\
\cline { 2 - 6 } & 96 & 0.219 & 0.401 & $3.700 X 10^{6}$ & $\mathrm{y}=-2.635+0.401 \mathrm{x}$ \\
\hline
\end{tabular}

Figure.1 Morphological characters of B. thuringiensis ABt 10 (A) Phase contrast Micrograph $(400 \mathrm{X})(\mathrm{B})$ Bright field micrograph of Spores
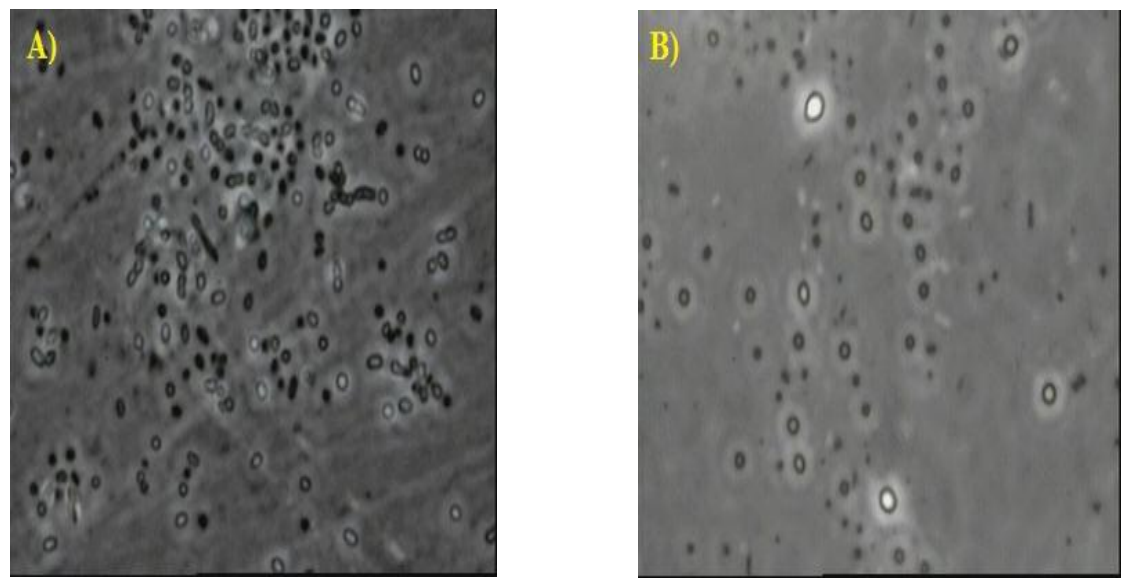
Figure.2 Cultural characters of B. thuringiensis ABt 10 (A) Colony on MYP Agar (B) Gram's staining
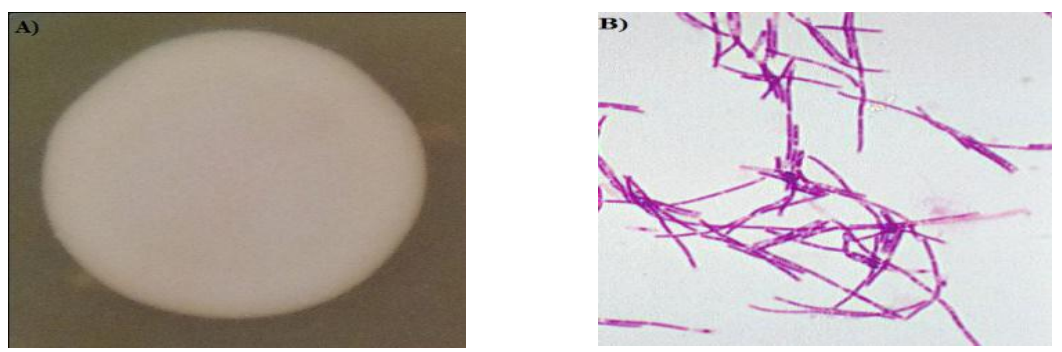

Figure.3 Symptoms of B. thuringiensis isolate ABt10 on H. armigera and S. litura A) Healthy larvae of $H$. armigera, B) Dead larvae of $H$. armigera, C) Healthy larvae of S. litura and D) Dead larvae of $S$. litura
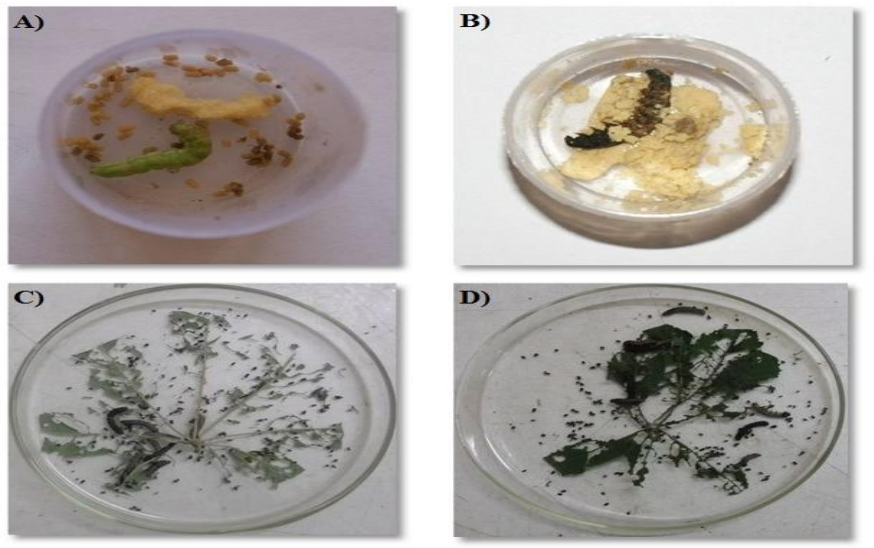

Figure.4 Phylogenetic tree based on 16S rRNA sequence of $B$. thuringiensis isolate $\mathrm{ABt} 10$

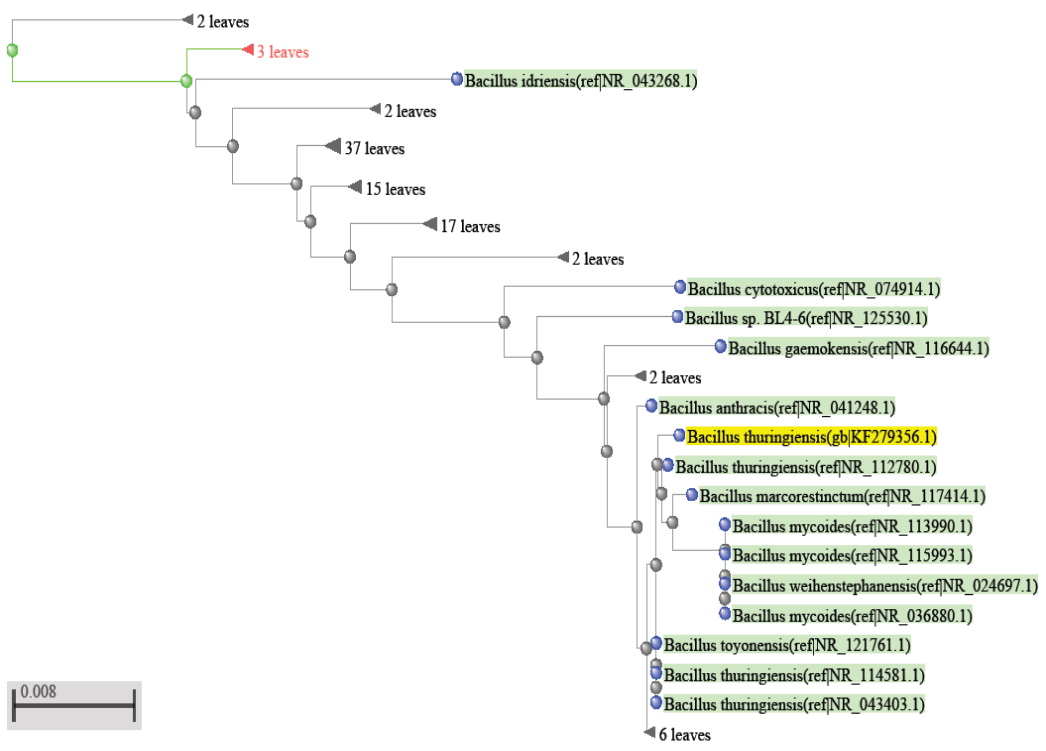


For 16S rRNA gene sequencing based identification, DNA was extracted from native $B$. thuringiensis isolate $\mathrm{ABt} 10$ as described by Wilson (1987). PCR amplification of $16 \mathrm{~S} r R N A$ gene from isolate $\mathrm{ABt} 10$ was carried out using universal primers (U27f and U1492r). 16S rRNA partial gene sequence of $\sim 1500$ bp was carried out and the output data were stored in FASTA. The output sequences were subjected for BLAST (Basic Local Alignment Search Tool) analysis to identify the cultures and to find out the nearest match of the cultures. Isolate $\mathrm{ABt} 10$ was identified as B. thuringiensis sp. with $99 \%$ similarity and $100 \%$ query coverage to $B$. thuringiensis sp. IAM 12077 and designated as $B$. thuringiensis $\mathrm{ABt} 10$ (Gene Bank Accession No. KF 279356). Additionally, the phylogenetic position of the isolate was also worked out within the available database of NCBI (presented as phylogenetic tree in Figure 4). The phylogenetic tree indicated, ABt 10 was placed in cluster one with more than $99 \%$ similarity with known $B$. thuringiensis sp. indicating phylogenetic closeness.

$\begin{array}{lllcc}\text { Laboratory bioassays } & \text { of } & \text { native } & B . \\ \text { thuringiensis isolate } & \mathrm{ABt} & 10 & \text { on } \\ \text { lepidopteran pest } & & & \end{array}$

Native B. thuringiensis isolate $\mathrm{ABt} 10$ was systematically tested through bioassay by Diet contamination technique given by Navon et al., (1990) against second instar larvae of $H$. armigera and $S$. litura to quantify the optimum bacterial dose for its effect for the suppression of the pest.

Spore-crystal mixture of $B$. thuringiensis isolate ABt 10 was tested at $10^{7}, 10^{8}$ and $10^{9}$ concentrations with that of Btk HD-73 (standard check). The larval mortality was recorded from $24 \mathrm{~h}$, after the treatment, at an interval of $24 \mathrm{~h}$ up to $168 \mathrm{~h}$. Amongst the different concentrations of $B$. thuringiensis isolate $\mathrm{ABt} 10$ tested; mortality started after
$24 \mathrm{~h}$ in $\mathrm{T}_{3}$ (B. thuringiensis isolate ABt 10@ $10^{9}$ spore crystal mixture/ $\mathrm{cm}^{3}$ diet) and was significantly superior over control. Larval \% mortality was observed to increase with a consequent increase in dose as well as time up to $120 \mathrm{~h}$; however, the quantum of increase lowered after $96 \mathrm{~h}$ of the treatment. All the treatments were found effective from $24 \mathrm{~h}$ and $\mathrm{T}_{3}$ was the best among all the treatments of test, standard strain as well as control.

All the treatments exhibited significant differences in per cent mortality of the test insect $H$. armigera and $S$. litura amongst different treatments as well as control ranging from 0.91 to $69.53 \%$. $\mathrm{T}_{3}$ was found to be at par with B. thuringiensis HD-73 @ 109 spore crystal mixture/ $\mathrm{cm}^{3}$ diet at 24, 48, 72 and 96 $\mathrm{h}$ periods after treatment. No larval mortality was noticed in untreated control (Table 2 and 3) (Fig. 3).

The dose mortality response of $H$. armigera at different concentrations of $B$. thuringiensis isolate $\mathrm{ABt} 10$ was subjected to probit analysis and the $\mathrm{LD}_{50}$ value were calculated (Table 4). The $\mathrm{LD}_{50}$ value for $B$. thuringiensis isolate $\mathrm{ABt} 10$ against $H$. armigera was found to be $2.15 \times 10^{7}$ spores $/ \mathrm{ml}$ at $96 \mathrm{~h}$ with regression equation $\mathrm{y}=-3.801+0.518 \mathrm{x}, \mathrm{Chi}^{2}$ value 1.286 and slope of 0.518 and $S$. litura was found to be $3.7 \times 10^{6}$ spores $/ \mathrm{ml}$ at $96 \mathrm{~h}$ with regression equation $\mathrm{y}=-2.635+0.401 \mathrm{x}$, $\mathrm{Chi}^{2}$ value 0.219 and slope of 0.401 .

Laboratory evaluation of different $B$. thuringiensis subspecies showed that $10^{10}$ spore $/ \mathrm{ml}$ concentration caused $100 \%$ mortality of larvae of the $H$. armigera during leaf bioassay (Rehman et al., 2002). According to Chandrashekar et al., (2005) B. thuringiensis var. kurstaki HD-1 based formulations are mostly used for lepidopteran control, but HD-73 showed higher mortality than HD-1 by 3.2-fold. HD-73 showed relatively higher mortality than $\mathrm{HD}-1$ to neonates of $H$. armigera. 
In this study, isolate ABt 10 shown the best performance during primary toxicity test and in bioassay in laboratory conditions. This isolate can be tested in field for its potency and can be developed commercially as a formulation. The research work presented here opens the door for future research on developing a novel $B$. thuringiensis of Middle Gujarat farmers for biological pest control.

Based on the results obtained from present investigations, it is concluded that modified method applied for isolation of $B$. thuringiensis from soil revealed good results and can be very useful in future. According to cultural, morphological, biochemical characters, $16 \mathrm{~S}$ rRNA based molecular phylogenetic analysis and primary toxicity tests, B. thuringiensis ABt 10Accn No. KF 279356 found to be the most promising as biocontrol agent against $H$. armigera and $S$. litura.

\section{Acknowledgements}

I would like to acknowledge Late Dr. J. J. Jani for invaluable, judicious, constant inspiration and thorough guidance, active persuasion and supervision, revealing suggestions and diligent efforts throughout the course of my study. Also I thank Dr. R. V. Vyas (Professor and Head, Department of Agricultural Microbiology) for encouragement and advice concerning the research work.

\section{References}

Ashokan, R. and Puttaswamy. (2007) Isolation and Characterization of Bacillus thuringiensis Berliner from soil, leaf, seed dust and insect cadavers. J. Bio. Control. 21, 83-90.

Chandrashekar, K., Kumari, A., Kalia, V. and Gujar G. T. (2005) Baseline susceptibility of the American bollworm, Helicoverpa armigera (Hubner) to Bacillus thuringiensis Berl var. Kurstaki and its endotoxins in India. Current Science. 88, 167-175.

Crickmore, N., Zeigler, D.R., Feitelson, J., Schnepf, E., Van Rie, J., Lereclus, D., Baum, J. and Dean, D.H. (2014). Bacillus thuringiensis Toxin Nomenclature. $<$ http://www.lifesci.sussex.ac.uk/Home/N eil_Crickmore/Bt/>.

El-kersh, T.A., Al-sheikh, Y.A., Al-akeel, R.A. and Alsayed, A.A. (2012) Isolation and characterization of native Bacillus thuringiensis isolates from Saudi Arabia. African Journal of Biotechnology. 11, 1924-1938.

Finney, D.J. (1971). Probit analysis, third edition. Cambridge University press, London.

Gomez, K.A. and Gomez, A.A. (1984) Statistical procedures for agricultural research. Willey Inter Science Publication. New York. Pp. 219.

Halt, J.G., Krig Peter, N.R., Sneath, H.A., Staley, J.T. and William, S.T. (1994) Burgey's Manual of Determinative Bacteriology $9^{\text {th }}$ edn. Pub.: William and Wilkins, Baltimore. Pp. 559.

Jurat-Fuentes, J.L. and Jackson, T.A.(2012) Bacterial entomopathogens. In: Vega, F.E., Kaya, H.K. (Eds.), Insect Pathology, second ed. Academic Press, San Diego, Pp. 265-349.

Kaur, P., Joshi, N. and Brar, K.S.(2006) Morphological and biochemical characterization of Bacillus thuringiensis Berliner isolates and their evaluation against Plutella xylostella Linnaeus. $J$. Bio. Control. 20, 191-195.

Lacey, L.A. and Goettel, M.S.(1995) "Current developments in microbial control of insect pests and prospects for the early 21st century." Entomophage. 40, 3-27.

Liang, H., Liu, Y., Zhu, J., Guan, P. and Li, S.(2011) Characterization of cry2-type genes of Bacillus thuringiensis strains from soil-isolated of Sichuan basin, China. Braz. J. Microbiol. 42, 140-146.

Martin, P.A.W. and Travers, R.S. (1989) World-wide abundance and distribution 
of Bacillus thuringiensis isolates. Applied Environmental Microbiology. 55, 24372442.

Morales-Ramos, J.A., Guadalupe Rojas, M. and Shapro-Ilan, D.L. (Eds.) (2014) Mass Production of Beneficial Organisms. Elsevier, Amsterdam, pp. 483-517.

Navon, A., Klein, M. and Braun, S.(1990). Bacillus thuringiensis potency bioassays against Heliothis armigera, Earias insulana and Spodoptera littoralis larvae based on standardized diets. Journal of Invertebrate Pathology. 55, 387-393.

Patel, D.J. (2006) Studies on Bacterial Isolates for Control of Lepidopteran Pest Helicoverpa armigera in Agriculture. Ph.D. Thesis (Microbiology), Gujarat University.

Patel, H., Patel, H., Vyas, H., Jani, J. and Vyas, R.(2013) Modified method for selective enrichment and isolation of Bacillus thuringiensis from soil. Biocontrol Science and Technology. 23, 470-473.

Perez, E., Sulbaran, M., Ball, M. and Yarzabal, L.A.(2007) Isolation and characterization of mineral phosphate-solubilizing bacteria naturally colonizing a limonitic crust in the south-eastern Venezuelan region. Soil Biol Biochem. 39, 2905-2914.

Poinar, G.O. and Thomas, G.M.(1984) Identification of the categories of insect pathogens and parasites. In: Laboratory Guide to Insect Pathogens and Parasites. Plenum Press- New York and London, 1st Edition. pp: 79-86.

Rehman, M.Z., Zafar, A.U., Nasir, I.A. and Shiekh, R. (2002) Comparative Study of Bacillus thuringiensis Biopesticides against Cotton Bollworms. Asian Journal of Plant Sciences. 1, 574-576.
Sambrook, J., Fritsch, E.F. and Maniatis, T.(1989) Analysis and cloning of eukaryotic genomic DNA in Molecular cloning. Cold Spring Harbor Laboratory Press. pp: 9-19.

Sanahuja, G., Banakar, R., Twyman, R.M., Capell, T. and Christou, P. (2011) Bacillus thuringiensis: a century of research, development and commercial applications. Plant Biotechnology Journal. 9, 283-300.

Steel, R.G.D. and Torrie, J.H. (1980) Principal and procedure of Statistic- A Biometrical Approach. Mc-Grow hill coga kusha Ltd., New Delhi 2nd Edition. Pp. 137.

Tanada, Y. and Kaya, H.K. (1993) Insect Pathology, Academic Press, San Diego.

Torres-Quintero, M.C., Arenas-Sosa, J., Hernández-Velázquez, V.M., SuárezRodríguez, R. and Peña-Chora, G. (2015) Signs of Bacillus thuringiensis (Bacillales: Bacillaceae) Infection in Myzus persicae (Hemiptera: Aphididae): Koch's Postulates. Florida Entomologist. 98(2), 799-802.

van Frankenhuyzen, K. (2009) Insecticidal activity of Bacillus thuringiensis crystalproteins. J. Invertebr. Pathol. 101, $1-16$.

Weisburg, W.G., Barns, S.M., Pelletier, D.A. and Lane, D.J. (1991) 16S ribosomal DNA amplification for phylogenetic study. J Bacteriol.173, 697-703.

Whiteley, H.R and Schnepf, H.E.(1986) The molecular biology of parasporal crystal body formation in Bacillus thuringiensis. Annu Rev Microbiol. 40, 549-76.

Wilson, K. (1987) Preparation of genomic DNA from bacteria. In: Current protocols in Molecular Biology. 1.

\section{How to cite this article:}

Ankit S. Patel, Harsha N. Shelat and Hiren K. Patel 2018. Isolation and Insecticidal Potential of Native Bacillus thuringiensis against Helicoverpa armigera and Spodoptera litura. Int.J.Curr.Microbiol.App.Sci. 7(02): 1330-1339. doi: https://doi.org/10.20546/ijcmas.2018.702.162 